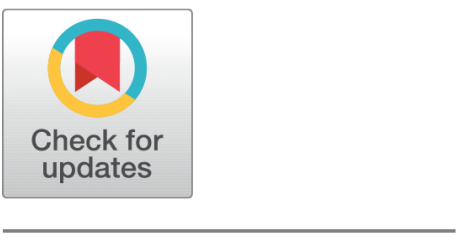

OPEN ACCESS

Received: 12-05-2020

Accepted: 13-06-2020

Published: 06-07-2020

Editor: Dr. Natarajan Gajendran

Citation: Das R, Gogoi B, Jaiswal MK (2020) Soil loss assessment in

Sadiya Region, Assam, India using remote sensing and GIS. Indian Journal of Science and Technology 13(23): 2319-2327. https://doi.org/ 10.17485/IJST/v13i23.588

*Corresponding author. Ratul Das

Dept. of Geography, Cotton College (GU), Guwahati, 781001, Assam, India

dratul.das@gmail.com

Funding: None

Competing Interests: None

Copyright: @ 2020 Das, Gogoi, Jaiswal. This is an open access article distributed under the terms of the Creative Commons Attribution License, which permits unrestricted use, distribution, and reproduction in any medium, provided the original author and source are credited.

Published By Indian Society for Education and Environment (iSee)

\section{Soil loss assessment in Sadiya Region, Assam, India using remote sensing and GIS}

\author{
Ratul Das $^{1 *}$, Barnali Gogoi ${ }^{2}$, Monoj Kumar Jaiswal ${ }^{3}$ \\ 1 Dept. of Geography, Cotton College (GU), Guwahati, 781001, Assam, India \\ 2 Department of Geography, Cotton University, Guwahati, 7810012, Assam, India \\ 3 Centre for Studies in Geography, Dibrugarh University, Dibrugarh, Assam, India
}

\section{Abstract}

Objectives: This study focuses on identifying areas of intense soil erosion in Sadiya, a subdivision of Tinsukia district of Assam in India to facilitate appropriate implementation of soil management and conservation schemes in an administrative unit. Methods: A comprehensive methodology of Remote Sensing (RS) and Geographical Information System (GIS) is implemented with an empirical model called the Revised Universal Soil Loss Equation (RUSLE). RUSLE is the best model to assess soil loss creating different raster layers in GIS. Findings: This study estimates about 443865 tons of soil loss occurs in Sadiya region annually. The maximum rate of soil loss recorded in Sadiya region is $888.26 \mathrm{t}$ $\mathrm{ha}^{-1}$ year $^{-1}$ the average soil loss estimated for the region is $5.45 \mathrm{t} \mathrm{ha}^{-1}$ year $^{-1}$. In addition, a final soil loss map is also created to show the zones of varied soil erosion rates/intensities. Applications/Improvements: The use of RS and GIS in soil loss estimation gives highly accurate result and can be used for extensive area with low cost. The study reveals that soil loss is a serious issue in the region where agriculture is the main economic activity. The outcome of the study may be used directly to address the hazard through management practices.

Keywords: Soil erosion; Assam; remote sensing; GIS; soil loss estimation

\section{Introduction}

Every year, in India it is estimated that about 5 billion tons of soil loss occurs annually with an average of $16 \mathrm{ton} / \mathrm{ha}^{(1)}$. The soil loss in India is more common in Western-Ghat and Himalayan region ${ }^{(2,3)}$. Nowadays, the soil loss and erosion due to strong water force are considered as world's major environmental hazard ${ }^{(4,5)}$ as it has a great impact on the environment and human economy. Therefore, a detailed and quantitative assessment is required to estimate the actual amount and nature of erosion in a region for sustainable land planning and management ${ }^{(6,7)}$.

Numerous studies have been conducted to understand the soil loss dynamics since last quarter of twentieth-century and many empirical and mathematical models for estimating soil loss have been developed ${ }^{(6,8-10)} . \mathrm{I}^{\mathrm{n}}$ this $\mathrm{t}$ tudy, we used the Revised Universal Soil Loss Equation ${ }^{(9)}$ model to estimate soil loss from Sadiya region and prepare 
soil loss map. The RUSLE is an improved version of the Universal Soil Loss Equation (USLE) ${ }^{(10)}$, which includes more diverse enhance methodologies and databases ${ }^{(6)}$. Due to its reliability and accuracy, several researchers used RUSLE in GIS platform to estimate soil loss in their specific regions, especially in India such as ${ }^{(2,11-14)}$ and many more. The findings of this research can help land managers and decision-makers to tackle the damages arise due to soil loss by providing adequate information on soil loss zones and the rates of soil loss.

\section{Study Area}

The region Sadiya is a sub-division of Tinsukia district, located in the north-eastern part of Assam, India. The latitudinal and longitudinal extension of the region is $27^{\circ} 45^{\prime} \mathrm{N}$ to $27^{\circ} 59^{\prime} \mathrm{N}$ and $95^{\circ} 25^{\prime} \mathrm{E}$ to $95^{\circ} 58^{\prime} \mathrm{E}$ respectively ( Figure 1 ). The total geographical area of the region is $789.95 \mathrm{sq} \mathrm{km}$, with a total population of 1,04,948 (2011). The region is characterized by alluvial plain which is bisected by river Kundil and surrounded by three major tributaries of river Brahmaputra viz, Dibang and Dihang River in the west and Lohit River in the south. The region comprises of three physiographic units old alluvium, new alluvium and piedmont zone. The region maintains a very gentle slope, highest elevation records $195 \mathrm{~m}$ and lowest elevation records $120 \mathrm{~m}$ above the mean sea level (MSL). The region experiences tropical monsoon climate where summer seasons are wet and winters are dry. The average rainfall of the region is about $275.9 \mathrm{~cm}$ in a year.

Agriculture is the primary economic activity of the inhabitants of Sadiya region, about $25.41 \%$ population being directly dependent on agriculture ${ }^{(15)}$. Constant soil loss from cropland leads to degradation in soil fertility and therefore, it is essential to know the magnitude of soil loss from the region for developing conservation practices

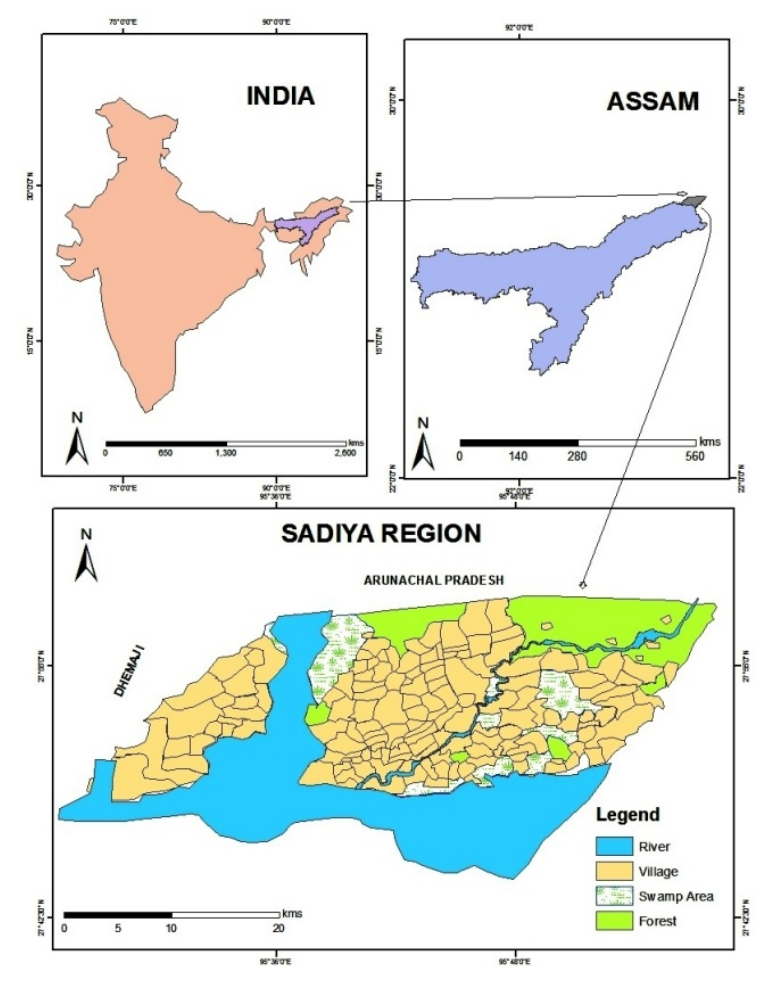

Fig 1. Study area.

\section{Materials and Methods}

To assess the magnitude of soil loss in Sadiya region, a diverse set of data from authentic sources have been used. The different sets of data used for the study with their sources are given in Table 1.

The RUSLE developed by United States Department of Natural resource conservation service ${ }^{(9)}$ is the principal method used in this study. It is an empirical model used worldwide to estimate soil loss from per unit land on an annual basis ${ }^{(14)}$. Here, using RUSLE we made an assessment of soil loss from the Sadiya region in a GIS platform. Various datasets required for this study 
Table 1. Details of various data sets used in the present study

\begin{tabular}{|c|c|c|c|}
\hline Type of data & Year & Author/Source & Title \\
\hline Topographical map & 1963 & Survey of India (SOI) & $\begin{array}{l}83 \mathrm{M}-5,6,9,10 \\
(1: 50,000)\end{array}$ \\
\hline Thematic maps & 1999 & $\begin{array}{l}\text { National Bureau of Soil Survey and Land Use } \\
\text { Planning (NBSS \& LUP), Nagpur }\end{array}$ & Soil map of Assam \\
\hline Rainfall Data & 2016 & India Meteorological Department & Daily rainfall data \\
\hline Topography Data & 2014 & $\begin{array}{l}\text { United States Geological Survey, EarthExplorer' } \\
\text { website }\end{array}$ & $\begin{array}{l}\text { Shuttle radar topographic mis- } \\
\text { sion } 30 \mathrm{~m} \mathrm{DEM}\end{array}$ \\
\hline Remote Sensing data & 2016 & $\begin{array}{l}\text { United States Geological Survey, EarthExplorer' } \\
\text { website }\end{array}$ & LANDSAT OLI-TIRS \\
\hline
\end{tabular}

were collected from several sources, as mentioned in Table 1. Later on, the obtained data ( Table 1) were processed in Arc GIS 10.2.1 and generate separate GIS layers for each factor of RUSLE in raster format to estimate soil loss from Sadiya Region. The overall schematic flow chart of the RUSLE method is illustrated in the Figure 2.

The RUSLE can assess soil loss from a given unit of land on a pixel-by-pixel basis, which is effective while attempting to identify the spatial soil erosion pattern present in a region ${ }^{(14)}$. The derivative equation of RUSLE is suggested by ${ }^{(10,16)}$

$$
A=R \times K \times L S \times C \times P
$$

Where: $\mathrm{A}$ is soil loss in $\mathrm{t} \mathrm{ha}^{-1}$ year $^{-1}$; $\mathrm{R}$ is the rainfall erosivity factor in $\mathrm{MJmm} / \mathrm{ha} / \mathrm{yr}$; $\mathrm{K}$ is the soil erodibility factor in $\mathrm{t} / \mathrm{MJmm} / \mathrm{ha}$; $\mathrm{L}$ is the slope length factor (dimensionless); $\mathrm{S}$ is the slope steepness factor (dimensionless); $\mathrm{C}$ is the cover and management factor (dimensionless); $\mathrm{P}$ is the conservation practices factor (dimensionless).

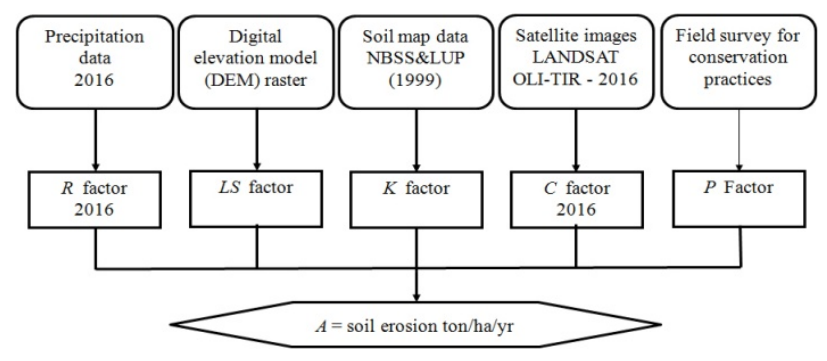

Fig 2. RUSLE method in flow chart

\section{Methodology}

\section{Factor or rainfall erosivity factor}

The rainfall and runoff erosivity factor $(\mathrm{R})$ computes the impact of a raindrop. It is a numerical representation of the rainfall ability to erode the soil ${ }^{(10)}$. It is estimated that a raindrop with a speed of 20-30 feet per sec has enough capacity to erode or detached the soil particles as high as 2 feet vertically ${ }^{(17)}$. In the RUSLE model, the rainfall erosivity is generally computed using the $\mathrm{EI}_{30}$ measurement with continuous and daily data ${ }^{(9)}$. Moreover, many researchers find out the R-factor using the average annual rainfall of longer periods as it includes the moderate cumulative effect ${ }^{(9)}$. However, it can be also applied at a time scale shorter than the year ${ }^{(18)}$ although it has some constraint such as single year data does not include the severe cumulative effect ${ }^{(9)}$. Thus the $\mathrm{R}$ factor is calculated by the following equation suggested by ${ }^{(10)}$ and $^{(14)}$ :

$$
R=\sum_{i=1}^{12} 1.735 \times 10^{\left(1.5\left(\log \left(\frac{p i^{2}}{P}\right)-0.8188\right)\right.}
$$

Here, pi is the monthly precipitation $(\mathrm{mm})$ and $\mathrm{p}$ is the annual precipitation $(\mathrm{mm})$.

The R-factor i.e. average rainfall erosivity factor is computed from rainfall data of four stations (2016) located in and around the region. The rainfall erosivity factor of Sadiya region varies from $1506.06 \mathrm{MJ} . \mathrm{mm} \mathrm{ha}^{-1}$ year $^{-1}$ year to $653.75 \mathrm{MJ} . \mathrm{mm}$ $\mathrm{ha}^{-1}$ year $^{-1}$ ( Table 2 and Figure 3). The north-eastern part of the region is more prone to soil erosion due to high rainfall. 
Table 2. Calculated R-factor of the region

\begin{tabular}{lll}
\hline Station (District) & Rainfall in mm & R-factor \\
\hline Tinsukia (Tinsukia) & 2552 & 307.74 \\
Dhemaji (Dhemaji) & 2268 & 351.36 \\
Roing (Lower Dibang Valley) & 5928 & 2054.25 \\
Tezu (Lohit Valley) & 2936 & 424.78 \\
\hline
\end{tabular}

Source: Computed in GIS

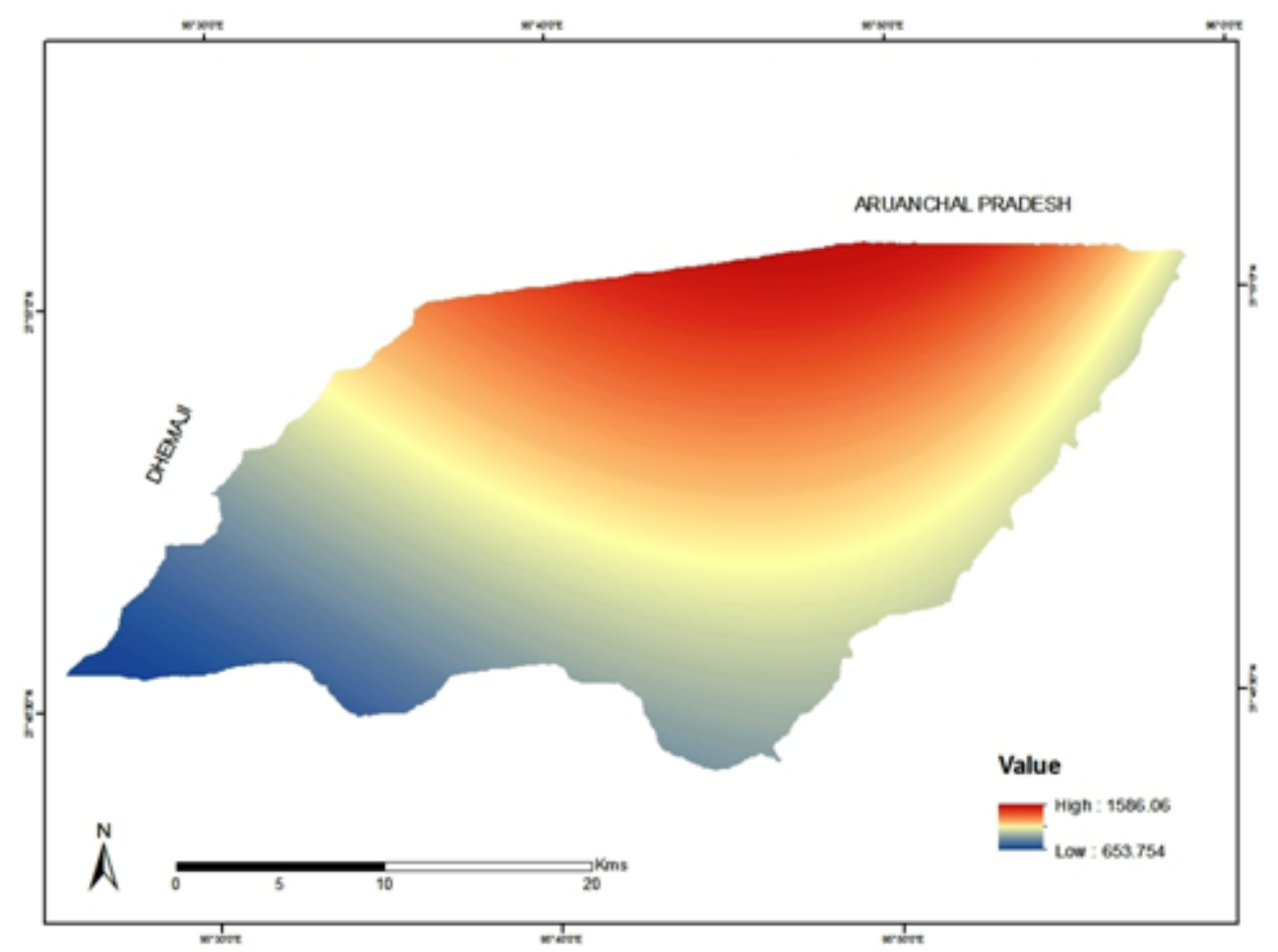

Fig 3. Rainfall erosivity map of Sadiya ( $\mathrm{R}$ factor)

\section{Factor or soil erodibility}

The Soil erosion generally depends on the characteristics of soils, such as parent material, texture, structure, organic matter content, hydraulic properties of the soil ${ }^{(19,20)}$. The soil erosion is more if it contains more sand ${ }^{(21)}$. Soil erodibility of the region is computed by nomograph of soil prepared by National Bureau of Soil Survey and Land Use Planning based on soil texture and contents of the soil. The K-factor values were estimated using the following equation suggested by ${ }^{(22)}$ as EPIC (Erosion productivity impact calculator)

$K=\{0.2+\exp [-0.0256 \operatorname{SAN}(1-\operatorname{SIL} / 100]\} *[S I L /(C L A+S I L)] 0.3 *\{1.0-0.025 C /[C+\exp (3.72-2.95 C)]\} \quad *\{1.0-0.7 S N 1 /[S N 1$

Where SAN is the sand content in \%, SIL is the silt content in \%, CLA is clay content in \%, C is the organic carbon in \% and SN1 $=1-S A N / 100$.

The K-factor of Sadiya region is computed based on the soil texture of the region The K-value varies from $0.02 \mathrm{t} / \mathrm{ha} /(\mathrm{MJ} . \mathrm{mm})$ to $0.049 \mathrm{t} / \mathrm{ha} /(\mathrm{MJ} . \mathrm{mm}$ ) in the region ( Table 3 and Figure 4). The Aeric Fluvaquent, a category of sandy loamy soil is more prone to the erosion as compared to the other category which is found in the riverine areas.

\section{Slope length and slope steepness or LS factor}

LS is the dimensionless factor of the RUSLE, its computation is the most complex aspects for relatively large areas ${ }^{(14)}$. The impact of slope length and steepness reflects on the degree of soil erosion ${ }^{(23)}$. To calculate the LS factor, the equation used 
Table 3. Computed K values.

\begin{tabular}{lll}
\hline Soil code & Soil Textural Class & K values \\
\hline AS 34 (Aeric Fluvaquent) & Sandy loamy soil & 0.049 \\
AS 42 (Typic Dystocrept) & Sandy loamy soil & 0.037 \\
AS 58 (Aquic Udifluviate) & Sandy loamy soil & 0.032 \\
AS 63 (Aquic Udifluviate) & Sandy Soil & 0.020 \\
\hline
\end{tabular}

Source: Agricultural Department, Assam.

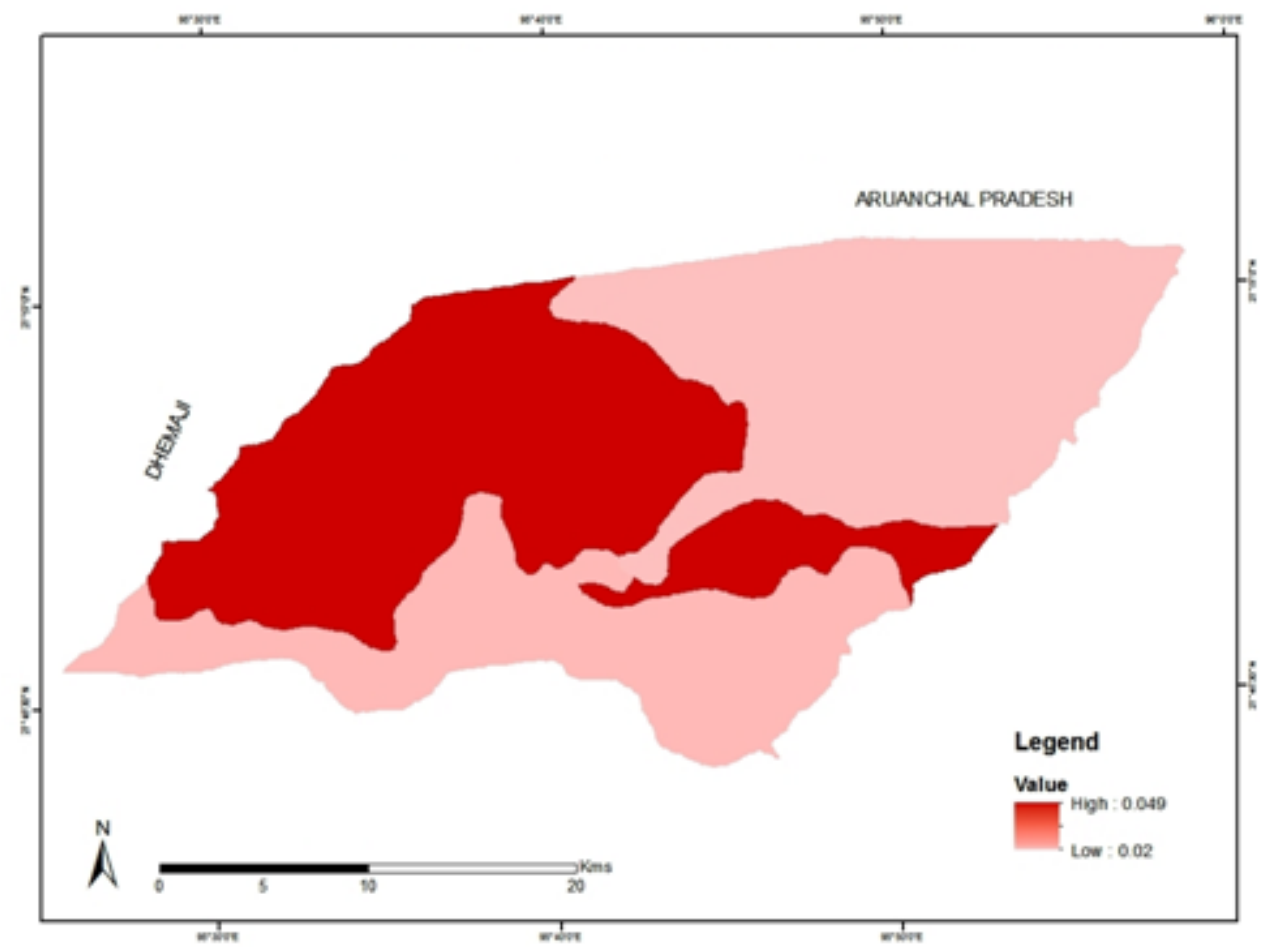

Fig 4. Soilerodibility factor (K factor)

by $^{(14)}$ and ${ }^{(24)}$ are employed in this study.

$$
L S=(A S / 22.13)^{m} \times(\operatorname{Sin} l / 0.09)^{n}
$$

Where AS = Upslope contributing area per unit width of pixel spacing, $\mathrm{l}=$ slope angle (degrees), $\mathrm{m}$ and $\mathrm{n}$ are exponent parameters of slope for slope length and gradient and the typical values of $\mathrm{m}$ and $\mathrm{n}$ are $0.4-0.6$ and $1.0-1.4$, respectively.

The variation of LS-factor in the region ranges from 46.87 to 0.07 ( Figure 5). The north-eastern part of the region shows higher LS value and the south-eastern part of the region shows lower LS-values due to variation in elevation. The higher LS values also recorded in areas near the river due to the higher slope length and steepness.

\section{Vegetation cover management or C factor}

It is one of the important factors of RUSLE which is a determinant to reduce the erodibility of the soil ${ }^{(16)}$. The vegetation cover is one of the most sensitive factors of soil loss ${ }^{(25)}$. The vegetation cover also acts as a defensive force to raindrops to reach the soil layer ${ }^{(26)}$. The satellite remote sensing data is used to calculate the $\mathrm{C}$ factor values. The NDVI and the following equation is used to generate the $\mathrm{C}$ factor ${ }^{(27)}$ value in the region after ${ }^{(25)}$ using Landsat OLI imagery (2016) in GIS environment.

$$
C=\exp \left(\alpha\left(\frac{N D V I}{\beta-N D V I}\right)\right]
$$

Where the value of $\alpha=-2$ and $\beta=1$ 


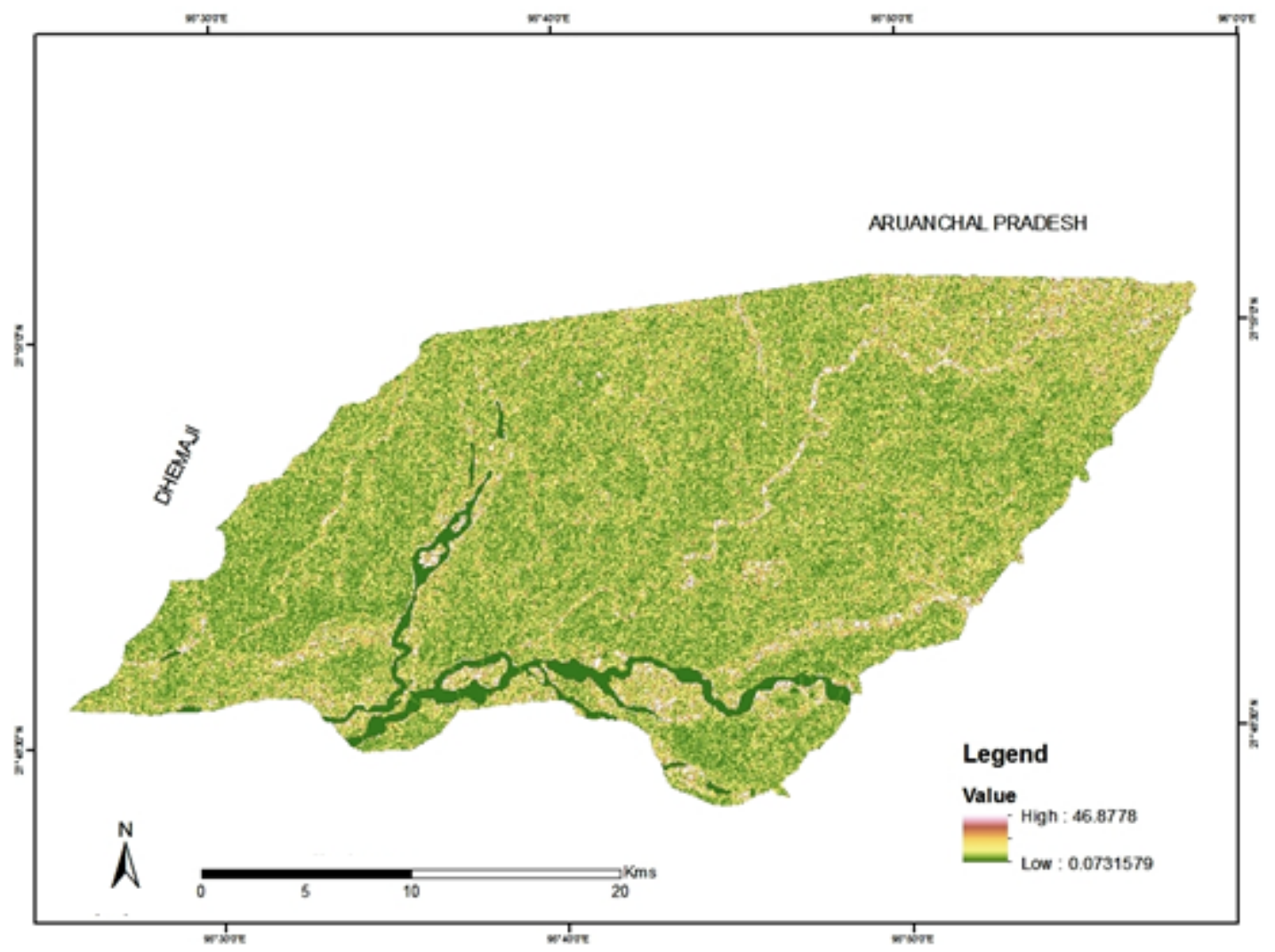

Fig 5. Topographic factor (LS factor).

The computed C-factor value ranges from 0.034 to 0.99 ( Figure 6). The equation generally shows the opposite relationship between the $\mathrm{C}$-factor and soil erodibility ${ }^{(28)}$. The higher $\mathrm{C}$ values are observed in the forest areas and lower values are observed in the agricultural fields or low vegetation cover.

\section{Support practice or P factor}

The $\mathrm{P}$ factor represents the pattern of practices on the amount and rate of erosion and soil loss ${ }^{(29)}$. The $\mathrm{P}$ values are very difficult to establish and are the least reliable of all the components of RUSLE ${ }^{(16)}$. The value of P-factor ranges from 0 to 1 ; where 0 stand for very good manmade erosion resistance and 1 stand for no man made erosion resistance facility or no known conservative practice $^{(4)}$. In the study region, no supporting manmade erosion resistance or conservative practices observed hence the P-value is considered as 1.

\section{Results and Discussion}

The annual soil loss of Sadiya region has been estimated for the year 2016, using RUSLE. Based on the integrated variables of RUSLE the annual soil loss of the region estimated; where it has been found that the region observed about 443865 tons soil loss annually, with an average annual soil loss in the region is $5.45 \mathrm{t} \mathrm{ha}^{-1}$ year $^{-1}$. The similar observation was also made in different river system of the Brahmaputra river basin such as Belsiri River ${ }^{(4)}$, Panchnoi River ${ }^{(16)}$, and Dhansiri River ${ }^{(28)}$. The average soil loss in Sadiya region is $5.45 \mathrm{t} \mathrm{ha}^{-1}$ year $^{-1}$ found to be lower than Dhansiri river basin $\left(34.6015 \mathrm{tha}^{-1}\right.$ year $\left.^{-1}\right)$ and Panchnoi river basin (5.63 $\mathrm{t} \mathrm{ha}^{-1}$ year $\left.{ }^{-1}\right)$ for the year 2015) but higher than the Panchnoi river basin $\left(3.64,4.35\right.$ and $4.94 \mathrm{t} \mathrm{ha}^{-1}$ year $^{-1}$ for the year 1990, 2000 and 2008 respectively) and Belsiri river basin $\left(0.05 \mathrm{t} \mathrm{ha}^{-1}\right.$ year $\left.{ }^{-1}\right)$. To estimate the magnitude of soil loss from different parts of the region we divide the region into six zones based on soil loss sensitivity, ranging from slight to very severe soil loss zones ( Table 4 and Figure 7 ). The class range of soil loss has been determined following suggested by ${ }^{(1,3)}$ and $(30)$ for Indian condition.

Most of the area of Sadiya region falls under slight soil loss zone $\left(<5 \mathrm{tha}^{-1} \mathrm{year}^{-1}\right)$, which comprises about $14.48 \%$ of 


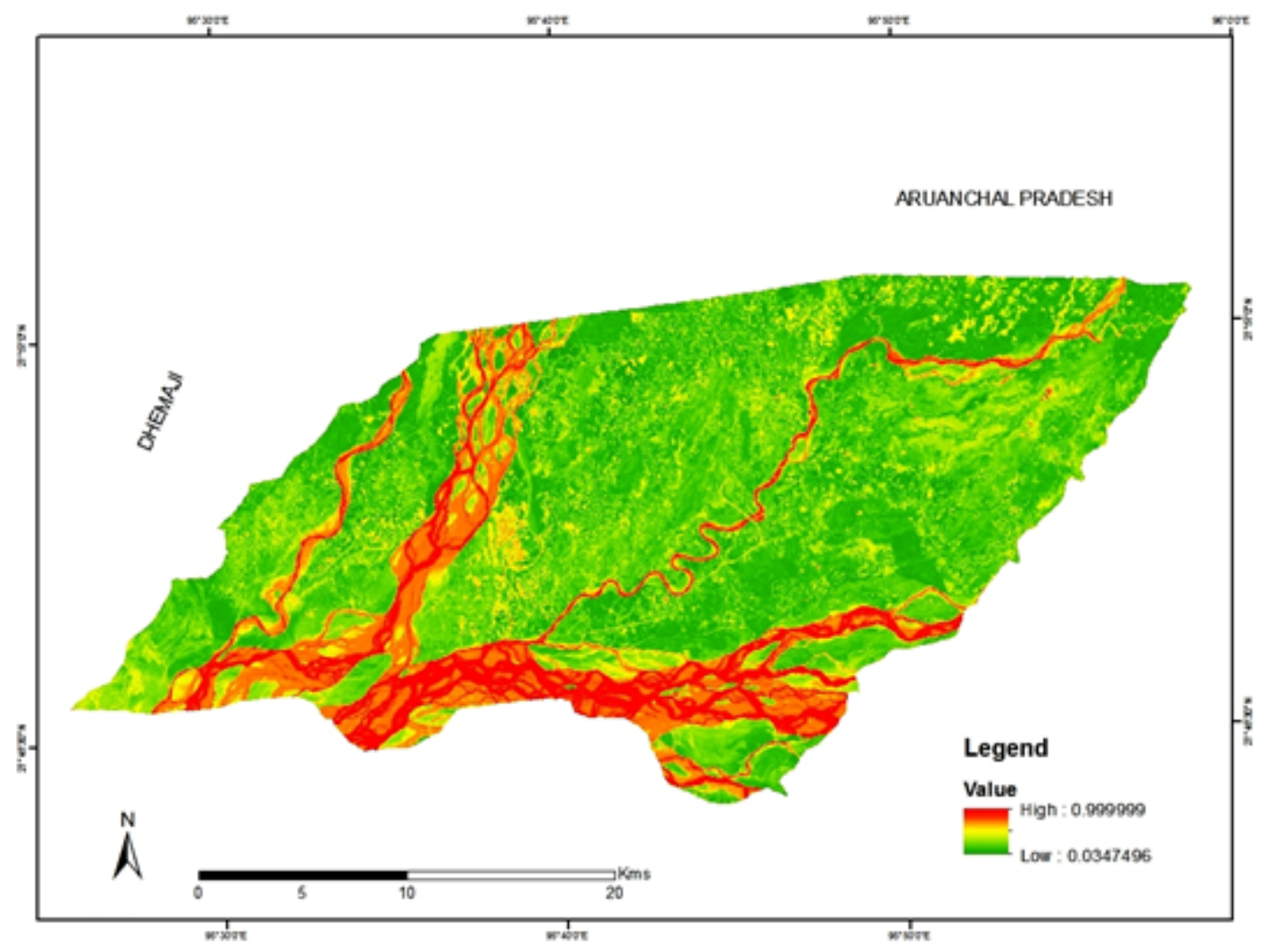

Fig 6. Crop cover management (C-factor)

Table 4. The class range of soil loss

\begin{tabular}{lllll}
\hline Soil erosion classes & $\begin{array}{l}\text { Average soil } \\
\text { erosion rate }\end{array}$ & $\begin{array}{l}\text { Total soil loss } \\
(\mathrm{t} / \mathrm{h}-1 / \mathrm{y}-1)\end{array}$ & Area in ha & Area in \% \\
Slight & $<5$ & 5190.18 & $11,786.26$ & 14.48 \\
Moderate & $5-10$ & 16736.99 & $59,808.93$ & 73.48 \\
High & $10-20$ & 4990.61 & $9,00.73$ & 11.06 \\
Very High & $20-40$ & 4470.84 & 587.23 & 0.72 \\
Severe & $40-80$ & 4447.54 & 166.92 & 0.2 \\
Very Severe & $>80$ & 4440.42 & 34.23 & 0.04 \\
\hline
\end{tabular}

the region. The moderate and high sensitivity zone (5-10 $\mathrm{tha}^{-1}$ year $^{-1}$ and 10-20 $\mathrm{tha}^{-1}$ year $^{-1}$ respectively) comprises about $84,54 \%$ area of Sadiya. Most of this zone lies between Dibang River and Kundil River, which is entirely comprised of agricultural fields and rural settlements. Other soil loss zones (very high, Severe and Very Severe) comprise about $0.96 \%$ land area. As expected the higher soil loss is observed in the areas of higher slope, high rainfall and less vegetation cover. Further, in this study it is observed that the high, very high, severe and very severe soil loss zones are mostly situated in the riverine areas and is a result of bank erosion and channel migration of the rivers in the region.

\section{Conclusion}

The RUSLE is one of the most reliable models to estimate soil loss throughout the world from a given unit of land. One of the most important drawbacks of RUSLE is less involvement of field measurement but it is a cost-effective model for estimating soil loss as compared to traditional methods; this model requires less physical effort. In addition, the region is monsoon regime where seasonal variation of rainfall and change in seasonal land-use should be made under consideration. Although the model 


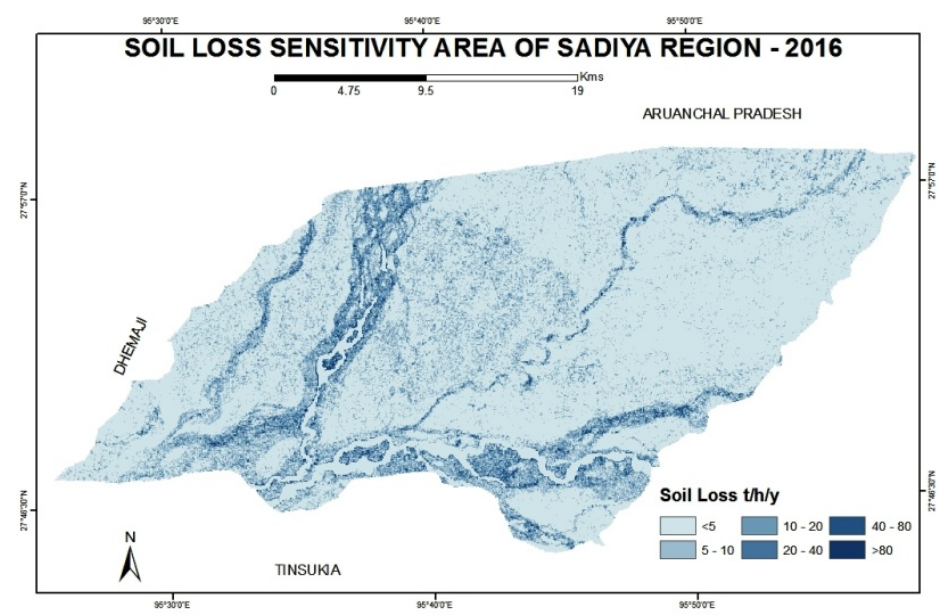

Fig 7. Soil loss sensitivity in Sadiya.

has high global acceptance, therefore, the model is used to estimates soil loss from Sadiya region which is located in the humid tropical climatic regime. This study estimates about 443865 tons of soil loss occurs annually in the region, with an average rate of $5.45 \mathrm{t} \mathrm{ha}^{-1}$ year $^{-1}$, which is quite high. In the study, it also observed that the quantity of soil loss is higher in the riverine areas and in areas of higher elevation with more gradient. Another important finding is that regular moderate soil loss occurs in areas of cultivation. The present study attempted to apply the RUSLE model in an administrative unit, although, it has been observed that most of the researchers apply this model in a physical unit such as river basin. The results of the study can help in formulating management strategies for sustainable land conservation practices.

\section{References}

1) Saroha J. Soil erosion: Causes Extent and Management in India. International Journal of Creative Research Thought. 2017;5(4):1321-1330.

2) Pandey A, Chowdary VM and Mal BC. Identification of critical erosion prone areas in the small agricultural watershed using USLE, GIS and remote sensing. Water Resources Management. 2017;21:729-746. Available from: https://doi.org/10.1007/s11269-006-9061-z.

3) Singh G, Babu R, Narain P, Bhusan LS and Abrol IP. Soil erosion rates in India. Journal Soil Water Conservation. 1992;47(1):97-99.

4) Kalita N and Sarmah R. Soil loss sensitivity in the Belsiri River basin using Universal Soil Loss Equation in GIS. International Journal of Current Research. 2016;8(3):28831-28838.

5) Sharma A. Integrating terrain and vegetation indices for identifying potential soil erosion risk area. Geo-Spatial Information Science. 2010;13(3). Available from: https://doi.org/10.1007/s11806-010-0342-6.

6) Chen G, Zhang Z, Guo Q, Wang X and Q W. Quantitative Assessment of Soil Erosion Based on CSLE and the 2010 National Soil Erosion Survey at Regional Scale in Yunnan Province of China. Sustainability. 2019;11. Available from: https://doi.org/10.3390/su11123252.

7) Zhu TX and Zhu AX. Assessment of soil erosion and conservation on agricultural sloping lands using plot data in the semi-arid hilly loess region of. China Journal of Hydrology: Regional Studies. 2014;2:69-83. Available from: https://doi.org/10.1016/j.ejrh.2014.08.006.

8) Benavidez R, Jackson B, Maxwell D and Norton K. A review of the (Revised) Universal Soil Loss Equation ((R)USLE): with a view to increasing its global applicability and improving soil loss estimates. Hydrology and Earth System Sciences. 2018;22:6059-6086. Available from: https://dx.doi.org/10.5194/hess22-6059-2018.

9) Renard KG, Foster GR, Weesies GA, Mccool DK and Yoder DC. Predicting Soil Erosion by Water: A Guide to Conservation Planning with the Revised Universal Soil Loss Equation (RUSLE), Agriculture Handbook,703, US Department of Agriculture. Washington, DC . 1997,. Available from: https: //www3.epa.gov/npdes/pubs/ruslech2.pdf.

10) Wischmeier WH and Smith DD. Predicting Rainfall Erosion Losses - A Guide to Conservation Planning. A Agriculture Handbook, 537. US Department of Agriculture Science and Education Administration. Washington, DC, USA . 1978,. Available from: https://naldc.nal.usda.gov/download/CAT79706928/ PDF.

11) Ganasri BP and Ramesh H. Assessment of soil erosion by RUSLE model using remote sensing and GIS - A case study of Nethravathi Basin. Geoscience Frontiers. 2016;7:953-961. Available from: https://dx.doi.org/10.1016/j.gsf.2015.10.007.

12) Patowary S and Sarma AK. GIS-Based Estimation of Soil Loss from Hilly Urban Area Incorporating Hill Cut Factor into RUSLE. Water Resources Management. 2018;32(10):3535-3547. Available from: https://dx.doi.org/10.1007/s11269-018-2006-5.

13) Srinivasan R, Singh SK, Nayak DC, Hegde R and Ramesh M. Estimation of soil loss by USLE Model using Remote Sensing and GIS Techniques - A Case study of Coastal Odisha, India. EURASIAN JOURNAL OF SOIL SCIENCE (EJSS). 2019;8(4):321-328. Available from: https://dx.doi.org/10.18393/ejss. 598120.

14) Jaiswal M and Amin N. The impact of land use dynamics on the soil erosion in the Panchnoi River Basin, Northeast India. Journal of the Geographical Institute Jovan Cvijic, SASA. 2020;70(1):1-14. Available from: https://dx.doi.org/10.2298/ijgi2001001j.

15) of India C. DISTRICT CENSUS HANDBOOK TINSUKIA SERIES-19 PART XII-A and B . 2011,.

16) Renard KG, Foster RG, Weesies GA, Porter GA and J. RUSLE Revised universal soil loss equation. Journal of Soil and Water Cocervation. 1991;46(1):30-33. 
17) Nikam... Available from: www.youtu.be/qkYt0q4Qth4.

18) Baiamonte G, Minacapilli M, Novara A and Gristina L. Time Scale Effects and Interactions of Rainfall Erosivity and Cover Management Factors on Vineyard Soil Loss Erosion in the Semi-Arid Area of Southern Sicily. MDPI AG . 2019,. Available from: https://dx.doi.org/10.3390/w11050978. doi:10.3390/w11050978.

19) Blanco-Canqui H and Lal R. Principles of Soil Conservation and Management. and others, editor . 2008,. Available from: https://doi.org/10.1007/978-14020-8709-7.

20) Pérez-Rodríguez R, Marques MJ and Bienes R. Spatial variability of the soil erodibility parameters and their relation with the soil map at subgroup level. Science of The Total Environment. 2007;378:166-173. Available from: https://dx.doi.org/10.1016/j.scitotenv.2007.01.044.

21) Mhangara P, Kakembo V and Lim KJ. Soil erosion risk assessment of the Keiskamma catchment, South Africa using GIS and remote sensing. Environmental Earth Sciences. 2012;65(7):2087-2102. Available from: https://dx.doi.org/10.1007/s12665-011-1190-x.

22) Sharpley AN and Williams JR. EPIC - Erosion Productivity Impact Calculator: Model Documentation (USDA Technical Bulletin Number 1768). Washington, DC . 1976,. Available from: https://naldc.nal.usda.gov/download/CAT10698097/PDF.

23) Prasannakumar V, Vijith H, Abinod S and Geetha N. Estimation of soil erosion risk within a small mountainous sub-watershed in Kerala, India, using Revised Universal Soil Loss Equation (RUSLE) and geo-information technology. Geoscience Frontiers. 2012;3(2):209-215. Available from: https://dx.doi. org/10.1016/j.gsf.2011.11.003.

24) Moore ID and Burch GJ. Modelling Erosion and Deposition: Topographic Effects. Transactions of the ASAE. 1986;29(6):1624-1630. Available from: https://dx.doi.org/10.13031/2013.30363.

25) Knijff MVD, Jones RJA, Montanarella L and European Soil Bureau Joint Research Centre. Soil Erosion Risk Assessment in Italy. and others, editor . 1999,. Available from: https://www.researchgate.net/publication/254764323.

26) Karaburun A. Estimation of C factor for soil erosion modelling using NDVI in Buyukcekmece watershed. Ozean Journal of Applied Sciences. 2010;3(1):7785 .

27) Panagos P, Borrelli P, Meusburger K, Alewell C, Lugato E and Montanarella L. Estimating the soil erosion cover-management factor at the European scale. Land Use Policy. 2015;48:38-50. Available from: https://dx.doi.org/10.1016/j.landusepol.2015.05.021.

28) Das T and Sarma AK. Estimation of annual average soil loss and preparation of spatially distributed soil loss map: A case study of Dhansiri river basin . 2017,. Available from: http://www.iitg.ac.in/bpccp/report/ANNEX2.pdf.

29) Rahaman SA, Aruchamy S, Jegankumar R and Ajeez SA. ESTIMATION OF ANNUAL AVERAGE SOIL LOSS, BASED ON RUSLE MODEL IN KALLAR WATERSHED, BHAVANI BASIN, TAMIL NADU, INDIA. ISPRS Annals of Photogrammetry, Remote Sensing and Spatial Information Sciences. 2015;II2/W2(2):207-214. Available from: https://dx.doi.org/10.5194/isprsannals-ii-2-w2-207-2015.

30) Narayana D and Babu R. Closure to Estimation of soil erosion in India. Journal of Irrigation Drain Engineering. 1983;109(4):408-410. 